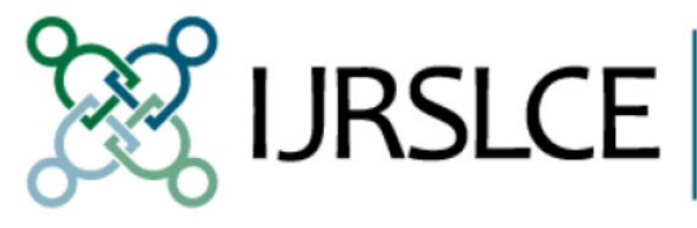

International Journal

for Research on

Service-Learning \&

Community Engagement

\title{
The Institutionalization of Service- Learning Projects in Argentine Schools
}

\section{Martin Ierullo}

This article was originally published at:

https://journals.sfu.ca/iarslce/index.php/journal/article/view/247/179

Recommended Citation

Ierulla, M. (2016). The institutionalization of service-learning projects in Argentine schools.

International Journal of Research on Service-Learning and Community Engagement, 4(1), 351354. 


\title{
The Institutionalization of Service-Learning Projects in Argentine Schools
}

\author{
Martin Ierullo \\ Center for Latin American Service-Learning and Solidarity
}

\begin{abstract}
This article discusses the theoretical and methodological standards used to evaluate the processes of institutionalizing service-learning experiences in Argentine schools. It also presents the major findings of a study conducted in 2014 that focused on primary and secondary schools participating in the Solidarity Schools support program "Creer para Ver" ("Believe to See"). The author organizes the analysis of the institutionalization process according to three dimensions: (1) project trajectory, (2) support of institutional actors, and (3) insertion of service-learning in daily school practices.
\end{abstract}

Keywords: institutionalization, evaluation, schools, service-learning

Between 2008 and 2014, the Center for Latin American Service-Learning and Solidarity (CLAYSS) and Natura Cosmetics Argentina developed the Solidarity Schools Support program "Creer para Ver" ("Seeing is Believing"). This program aimed to consolidate service-learning projects developed by primary and secondary schools across Argentina. In Argentina, several thousand schools operate robust, academically based service-learning programs, and students' participation in service-learning is a national requirement for high school graduation. Through the Creer para Ver program, CLAYSS provided technical support and guidance to more than 80 schools across the country.

The program included a systematic data collection and evaluation effort (Ierullo, 2011, 2013, 2014), from which quantitative and qualitative tools, indicators, and rubrics were created, along with typologies for classifying the projects. Data collection and analysis were based on a mixed-methods approach, with the majority of data comprising quantitative components (Johnson, Onwuegbuzie, \& Turner, 2007).

This article focuses on the analysis of institutionalization of service-learning experiences, explicating the theoretical and methodological criteria that were used. It also presents the main findings of a study conducted in 2014 centering on the 4,917 students, 427 teachers, and 93,275 other individuals affiliated with the 35 Argentine schools who participated in the "Creer para Ver" program that year.

\section{Indicators for Measuring the Institutionalization Process}

Generally, one way to measure the level of institutionalization of service-learning is to analyze the extent to which a project is undertaken as part of a school's overall pedagogical approach, rather than as an isolated initiative of a teacher or leadership team. In the context of this study of the institutional process, the following dimensions were considered: (a) project trajectory, (b) support of institutional actors, and (c) integration of service-learning in daily school practices. These dimensions were measured using a series of instruments and methods, including:

1. self-administered questionnaires to and semi-structured interviews with teachers responsible for the service-learning projects at schools participating in the program. Using these instruments, information about the implementation of the projects was collected.

2. surveys to students participating in the projects captured data about the activities that were developed and the students' assessments of them. 
3. reports written by CLAYSS professionals who were responsible for monitoring the projects. The reports detailed the activities of the service-learning projects under the guidance and authority of the institution.

These standardized instruments were applied annually at the schools that integrated the Creer para Ver program. After the data were gathered, a descriptive analysis of the status of the participating schools was conducted. The analysis was then used to inform a longitudinal study conducted between 2010 and 2014 which identified and examined the trajectories of the implemented projects.

\section{Dimension 1: Project Trajectory}

This dimension relates to the strategies used by teachers and other institutional actors to give continuity and visibility to service-learning experiences. While such strategies could be revealed using qualitative data collected through interviews and observations, they could also be identified using two "proxy" indicators that express the results of the implementation of the strategies: (1) project length, and (2) awards or other external recognition received. In relation to the 35 schools participating in the Creer para Ver program, the data analysis found that the service-learning experiences at the participating schools lasted an average of 5.31 years (ranging between 1 and 19 years) from the time they were initiated. Considering the high level of teacher mobility in Argentine schools, this figure is encouraging, as it suggests that service-learning is sustained in schools despite ongoing changes in the teaching staff.

Data from the interviews revealed that, in most cases, teachers or directors took the initiative to implement service-learning practices. This supported the idea that service-learning represents an alternative pedagogical approach that teachers more frequently select (in comparison with other available pedagogical approaches) to guide their teaching practices. While, in most cases, the service-learning effort was initiated by the teachers and/or school directors, this does not necessarily suggest that students played a minimal role. On the contrary, the active role of teachers and directors was a factor that in many cases enhanced students' proactive facilitation and advancement of the service-learning agenda. This active involvement moved students away from playing a passive or "laissez-faire" role in the effort; it also foregrounded the importance and value of empowering students to assume engaged, directive responsibilities in developing and shaping the overall educational work (Freire \& Shor, 2014). Finally, it should be noted that most of the projects ( $63 \%$ of 35 projects) received some kind of award or recognition, ${ }^{1}$ highlighting the visibility that these projects acquired at local and national levels.

\section{Dimension 2: Support of Institutional Actors}

This dimension relates to the degree of support that the coordinating teacher receives from other teachers and directors to develop a project. For this study, the following three groups of indicators (subdimensions) were considered: (1) the participation of the leadership team, (2) the participation of other teachers, and (3) the inclusion of service-learning in the Institutional Project Plan-an instrument generated via the active participation of various institutional actors that outlines the institutional mission and frames the educational plan and teaching activities.) In most of the projects analyzed (97\%), the leadership team participated through various actions based on the context of each individual servicelearning experience. However, the majority played an active role in the daily support and coordination of service-learning projects (e.g., facilitating the coordination of actions by different teachers, creating instances of exchange between the actors involved, promoting coordination with other community institutions, and obtaining permits and resources necessary for students' trips to the community).

In addition, teachers' participation in service-learning projects increased consistently over the course of the study (see Table 1).

\footnotetext{
${ }^{1}$ In 2000, the Argentinian Ministry of Education established the "Solidarity Schools" Presidential Award, a national grant program aimed at rewarding schools that institute outstanding service-learning projects and initiatives.
} 
Table 1. Average Number of Teachers Participating Annually in Service-Learning Projects by Institution

\begin{tabular}{crrr}
$\mathbf{2 0 1 1}$ & $\mathbf{2 0 1 2}$ & $\mathbf{2 0 1 3}$ & $\mathbf{2 0 1 4}$ \\
\hline 10.6 teachers & 11 teachers & 11.4 teachers & 12.2 teachers \\
\hline
\end{tabular}

The incorporation of new teachers implies a better distribution of tasks associated with servicelearning projects. It also suggests that service-learning practice is becoming more prevalent and institutionalized in Argentine schools.

In $64 \%$ of the 35 projects studied, the students' families participated through different actions (e.g., accompanying students to activities in the community, finding resources for project development, etc.). Also, in $48 \%$ of all cases, graduate students were involved. Both findings indicated a sense of project ownership on the part of the educational community.

The findings of the study also revealed that service-learning was being institutionalized through its inclusion in the Institutional Project Plan. Indeed, 95\% of the 35 institutions in the study include the service-learning pedagogical proposal in the plan. Also in $79 \%$ of all cases, the service-learning project is explicitly mentioned in the plan.

\section{Dimension 3: Insertion of Service-Learning in Daily School Practices}

Although this dimension may be linked to the length of a service-learning project, it is not limited to this aspect. The permanence of a service-learning project does not necessarily involve integration with everyday or common practices (Dussel, 2006). In fact, many service-learning projects operate cocurricularly. Within this dimension, two sub-dimensions were identified: (1) students' participation, and (2) institutional time involved in the project. The study data showed, beginning in 2014, a reduction in the number of service-learning projects initiated by through students voluntarily. This suggests the beginning of a trend toward service-learning projects being incorporated into schools' institutional programs as mandatory practices.

In $85 \%$ of the 35 schools analyzed, there was a fixed weekly time spent on project implementation. The data findings revealed that, on average, institutions devoted seven hours per week to each servicelearning project. This time spent on the projects is significant when compared with the average number of total weekly class hours in Argentine schools (about 25 hours per week). In this regard, more than $25 \%$ of the school week was spent on service-learning activities.

No less relevant, in $90 \%$ of the cases, most of the projects were developed and operationalized throughout the school year. Furthermore, the project implementation involved the use of both in-school time (in all cases) and after-school time (in $83 \%$ of cases). These indicators suggest that the servicelearning experiences were inserted more fully in the daily practices of the schools that were studied. Moreover, they imply a trend in which service-learning is perceived less as projects that students do and more as a way for teachers to address the teaching and learning processes.

\section{Conclusions}

The institutionalization of service-learning within primary and secondary schools is a complex process that involves the active participation of different actors in the educational community. The institutionalization process occurs when deliberate actions and explicit institutional decisions advance service-learning as an embedded educational practice within the curricula of the school day. Institutionalization is important because, as has been demonstrated in previous studies (Ierullo, 2013, in press), there is a statistical correlation between the quality of service-learning project implementation and the degree to which service-learning is institutionalized within a school. In other words, schools that have 
higher levels of service-learning institutionalization tend to initiative service-learning projects that achieve greater development of learning activities and community service.

The technical support and guidance provided by CLAYSS have arguably contributed to the improvement in the level of service-learning institutionalization at the sites that participated in the "Creer para Ver" program. In this regard, the measurement of the aforementioned indicators suggests that ongoing participation in the program might facilitate the further enhancement and ultimate institutionalization of service-learning at participating sites. Finally, as the evidence suggests, the evaluation tools and rubrics built have been useful for analyzing the different dimensions involved in the process of institutionalization and have helped to facilitate the technical support and guidance CLAYSS has provided to the sites.

\section{Author Note}

Martin Ierullo, Center for Latin American Service-Learning and Solidarity.

\section{Acknowledgements}

The author thanks Natura Cosmetics Argentina for providing financial support for the Solidarity Schools Support Program; all the teachers who provided the information required for the indicators development; and Candelaria Ferrara, who helped to facilitate the English translation and revision of this article.

\section{Correspondence}

Correspondence regarding this article should be addressed to Martin Ierullo, Centro Latinoamericano de Aprendizaje y Servicio Solidario, Yapeyú 283, CP 1202, Buenos Aires, Argentina. Phone: 54 011-41563791. E-mail: ierullo.martin@gmail.com

\section{References}

Dussel, I., (2006). Comentarios a las experiencias ganadoras del Premio Presidencial Escuelas Solidarias 2005. Tapia, N. (Ed.), Experiencias ganadoras del Premio Presidencial Escuelas Solidarias 2005. Buenos Aires: Ministerio de Educación de la Nación.

Freire, P., \& Shor, I. (2014). Miedo y osadía. La cotidianeidad del docente que se arriesga a practicar una pedagogía transformadora. Buenos Aires: Editorial Siglo XXI.

Ierullo, M. (2011). Informe de evaluación programa "Creer para Ver" 2011. Buenos Aires: CLAYSS.

Ierullo, M. (2013). Programa de apoyo a Escuelas Solidarias Creer para Ver, Natura Argentina CLAYSS: Informe de Evaluación 2012. Buenos Aires: CLAYSS. Retrieved from http://www.clayss.org.ar/06 investigacion/descargas/CLAYSS-Informe Creerparaver2012.pdf

Ierullo, M. (2014). El aprendizaje y servicio solidario en las escuelas: Informe de evaluación programa Creer para Ver: 2013. Buenos Aires: CLAYSS. http://www.clayss.org.ar/06 investigacion/descargas/Informe\%202013.pdf

Ierullo, M. (in press). Aprender y transformar la realidad. Informe de evaluación de las experiencias de aprendizaje y servicio solidario en las escuelas del programa Creer para Ver 2014. Buenos Aires: CLAYSS.

Johnson, R. B., Onwuegbuzie. A., \& Turner, L. (2007). Toward a definition of mixed methods research. Journal of Mixed Methods Research, 1(2), 112-133. 